\title{
Retraction Note to: DNAPL Migration in a Rough Fracture Under Various Wettability and Flow Conditions
}

\author{
Hang Bok Lee ${ }^{1}$
}

Published online: 21 August 2015

C) Springer Science+Business Media Dordrecht 2015

\section{Retraction Note to: Transp Porous Med (2015) 107:321-333 DOI: 10.1007/s11242-014-0438-9}

This article has been retracted at the request of the author.

This study (published in the Journal Transport in Porous Media: "DNAPL migration in a rough fracture under various wettability and flow conditions," Volume 107, Issue 2 (2015), Page 321-333) extended the author's previous experimental research by applying numerical simulation that was published in the Journal of Contaminant Hydrology, Title: Wettability-dependent DNAPL migration in a rough-walled fracture, Volume 113, (2010), Page 44-55.

Although there were some modifications and improvements through numerical modeling (MIP model), according to the author's advice, novel contribution is insufficient, and the overall conclusion is similar compared to his/her earlier published study.

The online version of the original article can be found under doi:10.1007/s11242-014-0438-9.

Hang Bok Lee

leehb@kigam.re.kr

1 Underground Space Department, Korea Institute of Geosciences and Mineral Resources, Daejeon 305-350, Republic of Korea 